\title{
Filter Device
}

National Cancer Institute

\section{Source}

National Cancer Institute. Filter Device. NCI Thesaurus. Code C49956.

A device designed to remove something from whatever passes through it. 